\title{
PIONEER
}

VOLUME 11, Issue 2, December 2019: 54 - 60

\section{ENHANCING WRITING SKILL OF TOURISM AND MANAGEMENT BUSINESS STUDENTS THROUGH MIND MAPPING}

\author{
Nurhalimah \\ Politeknik Negeri Banyuwangi \\ nurhalimah@poliwangi.ac.id
}

\begin{abstract}
The study identifies appropriate mind mapping techniques to enhance the Tourism and Business Management Students' writing ability. This particular research was categorized as action research which consists of some steps namely: planning, acting, observing, and reflecting. There were two kinds of data used in this research, qualitative data and quantitative data. The qualitative data were gained from classroom observation and interview and transformed into field notes and interview transcripts by using qualitative data analysis. The implementation of mind mapping as one of techniques successfully improved students' ability and motivation in learning writing. Mind mapping helped the students in generating and developing their ideas and help them easily in way of collecting information in writing descriptive text about tourism destination.
\end{abstract}

Keywords: mind mapping, writing skill

\section{INTRODUCTION}

English language has very important function for the human's life since the world globalization era. It is accepted as an International language of technology and trade. English language plays an important role in the world in some field such as education, economy, arts, political world, trade, science, and technology. English becomes the main subject for students in Indonesia especially in the formal education and it has been taught from elementary school up to university level. In addition, English is not frequently learned as a tool for understanding and teaching U.S or British cultural values (Brown, 2006). The purpose of English subject is to develop the ability to communicate both in oral and in written form skill in listening, speaking, reading, and writing. Simply speaking, all the students have to master the four language skills, namely listening, speaking, reading, and writing.

Writing is one of the language skills that must be mastered by the students, but writing is considered as one of the difficult skills to master. (Farbain and Winch, 1996) state that writing is difficult and very few people have the ability to write an essay at one sitting in a form that is adequate. In addition, (Ploeger, 2004) states that writing is 
one of those skills that many people, especially students; feel should be done easily and quickly, without extended thought or effort, to write well, however, can be difficult, even for professionals who write every day. Writing is one important skill that must be taught for the students. (Harmer, 1998) states that the reasons for teaching writing to students of English as a foreign language are for reinforcement, language development, learning style, and most importantly, writing is as a basic skill. Considering this reason, writing as a means of communication is demanded.

Based on observation in the teaching and learning process, the researcher found that the students still had difficulties to expand their ideas; they cannot improve their ideas in their writing a descriptive text, especially when they are asked to describe a tourism destination. The students should have an ability to expand their ideas to describe everything in their mind into a good a descriptive text, related to the topic that given by their teacher. In fact, their paragraph is very short and makes the reader confused. One of strategies to overcome the unsatisfactory condition stated above, the researcher proposes one of the strategies in teaching writing, especially in writing a descriptive text. It is mind mapping strategy, also called concept mapping, semantic mapping, spidergram, webbing, or clustering.

Mind mapping were developed by Tony Buzan in 1964 as a way of helping the students make notes that used only key words and images. Mind mapping are useful to expand students' ideas. According to (Langan, 2001) mind mapping is a strategy that can be used to generate material for a paper that is helpful for people who like to do their thinking in visual way. It helps writers think and explore about a topic and its details. It also shows the relationship between ideas so as to allow the students to develop them into a passage more easily. This strategy is expected to help the students in generating ideas before writing so that they can write smoothly based on the mapping that they have made. 
The form of mind mapping that developed by (Hamp- Lyons, 2006) as follow:

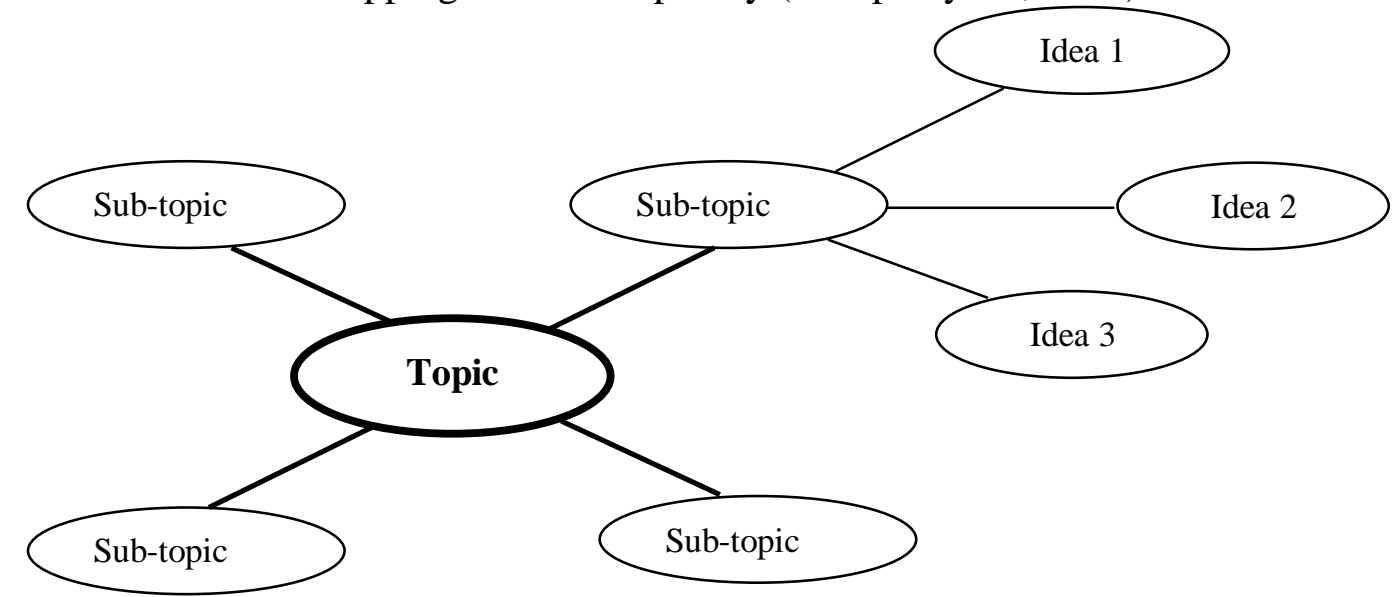

Figure 1 Mind Mapping developed by (Hamp- Lyons, 2006)

The above figure shows that the topic is developed by discussing each sub topic with ideas or component. The idea of mind mapping is to start with main topic and then what that topic is composed is determined. Sub point of mind mapping around the idea component. When the first main idea is completely developed, it is followed by the subtopic and the ideas component. The order can be based on the degree of the importance and the logic of the ideas.

There is no exact step to create mind mapping. It could be modified based on the needs of the writer. (Langan, 2001) confirms that keep in mind that there is no right or wrong way of mind mapping. For instance, for younger students, mind mapping can be constructed for a paragraph in which main ideas and details are integrated into map. On the other hand, older students may construct mind mapping for longer writing by omitting the details and including the ideas that support the main ideas only. Based on the statements above, mind mapping can be constructed for writing a paragraph in which main ideas and details are integrated into map and the steps of making mind mapping could be varied to suit different purposes of writing.

Mind mapping provides many advantages for the process of writing. It benefits the writer in developing and organizing ideas as prewriting activity, developing the content, and revising the draft as well. The main benefits of using mind mapping strategy is during prewriting activity. According to (Gerson, 1993), mind mapping is an excellent prewriting technique because it easily allows the writer to gather information and organize our thoughts. All the explanations above give clear description about the advantages of mind mapping for the writing activity, especially for prewriting activity 
as the parts of the writing process. It could be used for developing and organizing ideas. It can be stated that mind mapping is one of the effective strategies to improve the students' ability in writing descriptive text to describe about tourism destination.

Writing is a process of thought which we discover, organize, and communicate our thought to a reader. Then, (Stanley, 1992) defines writing as an activity that might be graphically portrayed as a triangle:

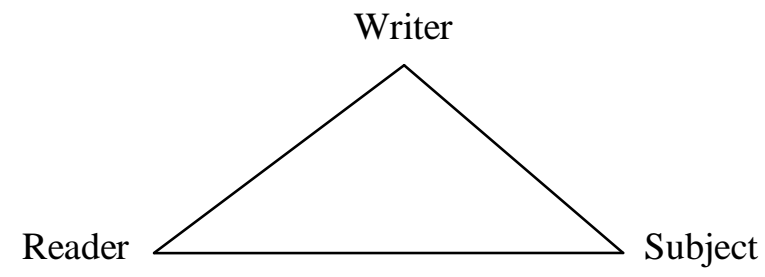

Figure 2.4 writing activity defines by (Stanley, 1992)

The purpose is to communicate about a subject to a reader. Here, the writers' feelings, knowledge, ideas about both the subject matter and the reader, and the writer must take both into account in order to communicate effectively. In general, the writing process covers three stages, namely prewriting, writing, and post writing. (Gerson, 1993) states that to produce successful technical writing, the writer need to approach writing as a 'process'. The process approaches are prewriting, writing, and rewriting.

\section{METHODOLOGY}

This study was action research study and conducted from August to September 2019 in the first semester of the academic year of 2019/2020. According to Kemmis and Taggart in (Sukardi, 2003) that action research is the way groups of people can organize the conditions under which they can learn from their own experiences and make their experience accessible to others. The subjects of the research were 40 students of the first grade of Tourism and Business Management Department at Politeknik Negeri Banyuwangi. This research is intended to give actions to improve the student's writing achievement in descriptive text in order to describe about tourism destination by using mind mapping strategy. Therefore, the classroom action research with the cycle model is applied in this research. According to Lewin in (Aqib, 2006), action research is a cyclic process, which consists of some steps namely: planning, acting, observing, and reflecting.

There were two kinds of data used in this research, qualitative data and 
quantitative data. The qualitative data were gained from classroom observation and interview and transformed into field notes and interview transcripts by using qualitative data analysis. The steps of the analyzing qualitative data was used to describe the teaching of writing by using mind mapping to improve the students' writing skill. The analysis was done to find out whether or not the research is successful. According to the analysis, the researcher knew whether or not the procedure of the teaching writing using mind mapping technique is successful. The quantitative data were gained from pre-test and post-test and transformed into writing score by using rubric of writing by Harmer. Then the mean scores of the students' scores in each test were compared by using Microsoft Excel program.

\section{FINDING AND DISCUSSION}

In doing this research, the researcher and also as a teacher delivered the teaching and learning process. There were two cycles in this research. In the end of each cycle, the researcher conducted a post-test to see and measure the students' improvement in writing. Before implementing the actions, the researcher conducted a pre-test to measure the students' writing ability. In this pre-test, the students were asked to write a descriptive text about tourism destination. Then the result of the students' writing performance was analyzed and transformed into writing score using scoring rubric of writing proposed by Harmer. There were some actions that were implemented by the researcher in the teaching and learning process; 1) using mind mapping as a strategy to teach writing, 2) providing reading section; 3) asking the student to write their own descriptive text about tourism destination; and 4) giving feedback to the students. Some of those actions had successful and unsuccessful effect in Cycle 1.

The implementation of mind mapping as one of techniques successfully improved students' ability and motivation in learning writing. Mind mapping helped the students in generating and developing their ideas and help them easily in way of collecting information in writing descriptive text about tourism destination. However, the students still had limited number of supporting ideas in their writing. This action was continued in Cycle 2 to gain better improvement in students' writing ability.

From the observation in teaching and learning process, the students still considered that the developing of mind idea was a difficult thing to improve. Therefore, the students still had less vocabulary and the paragraph still not consequence. Providing 
reading section combined with mind mapping in the stage of planning in writing process increased students' interest in learning. The students' vocabulary skill range widened. However, they still made frequent errors in capitalization, punctuation, and spelling. Ask the students to develop their descriptive paragraph about tourism destination using mind mapping strategy. Providing feedback to students' writing also improved the students' awareness and confident in writing. The students were able to know and study from their mistakes and errors in their writing. These two actions were continued in Cycle 2. Based on the result of students' writing performance in post-test 1, it can be seen that the students' improvement was not maximum since there were some obstacles found in the teaching and learning process. Therefore, the researcher modified some actions that could improve the students' writing ability better.

In cycle 2, the researcher used a passage longer than before. This action successfully improved the students' vocabulary mastery. The researcher also provided the students with both oral and written feedback. Oral feedback was given to the students through classroom discussion and question-answer session to save the time. Through the implementation of some modified actions, the students' writing ability improved significantly in Cycle 2. The results of the students' writing mean score are presented in the table below:

\begin{tabular}{|c|c|c|c|}
\hline Score & Pre- Test & Post- Test 1 & Post Test 2 \\
\hline Mean & 70.5 & 75.5 & 78.5 \\
\hline
\end{tabular}

Table 1. The Result of Students; Score

\section{CONCLUSION AND SUGGESTION}

Based on the result in discussion session, the researcher concludes that the implementation of mind mapping strategy can be an alternative solution to solve the students' difficulty in composing vivid descriptive text and make the students easy to generate and develop their ideas. The students were trained to write through the stages of writing. Before the students begin to write, they were given some alternative choice of telling sentences. The basic things in mind mapping that should be understood by the students are the telling sentence and the showing details. The telling sentence is the same as the main idea of the descriptive text which tells what is going to be described in the whole paragraph, while the showing details are the specific details of the telling 
sentence that should be developed into a showing paragraph or a simple description.

Some suggestion or recommendation for future researchers or other English teachers who have some problems with the teaching of writing are suggested to conduct a classroom action research concerning the application of the mind mapping strategy to improve the students' achievement in writing. In addition, it is suggested for another researcher to conduct the research on the use of the mind mapping strategy in teaching and learning process of writing lesson on other genres or different kind of texts, such as narrative, recount, etc. Mind mapping also can be used to teach other English skills.

\section{REFERENCES}

Aqib, Z. (2006). Penelitian Tindakan Kelas. Bandung: Yrama Wiodya.

Brown. (2006). Teaching Listening. New York: Cambridge University Press.

Farbain and Winch. (1996). Reading, Writing, and Reasoning; A Guide for Students (2nd edition). Philadelpia: Open University Press.

Gerson, G. a. (1993). Technical Writing Process and Product (2nd edition). California: Prentice- Hall, Inc.

Hamp- Lyons, L. a. (2006). Study Writing (2nd edition). Cambridge: Cambridge University Press.

Harmer, J. (1998). How to Teach English. London: Longman Group.

Langan, J. (2001). College Writing Skills with Reading (5th edition). New York: The McGraw- Hill.

Ploeger. (2004). Simplified Paragraph Skills. New York: NTC/ Publising Group.

Stanley, L. C. (1992). Ways to Writing, Purpose, Task, and Process (third edition). New York: Mc Millan Publising Company.

Sukardi. (2003). Metodologi Penelitian Pendidikan, Kompoetensi, dan Praktiknya. Yogyakarta: Bumi Aksara. 